\section{Klochan V., Kostyrko A., Bobrovskay N.}

\title{
SUBSTANTIATION OF ORGANIZATIONAL AND ECONOMIC COMPLEX FOR INCREASE OF SOCIAL RESPONSIBILITY OF BUSINESS IN UKRAINE
}

Об’єктом дослідження є організаційно-економічні процеси соціалізацї українського бізнесу. Одним з найбільш проблемних місць є формування адекватної стратегї поведінки українського бізнесу щодо навантаження на навколишнє середовище і обмеженні негативного впливу на екосистеми.

В ході дослідження використовувалися такі методи наукового дослідження: бібліографічнии; монографічний; метод логічного узагальнення; розрахунковий; порівняльний та метод системного підходу.

Проаналізовано динаміку позицї України за Індексом глобальної конкурентоспроможності, який також враховує соціальні ініціативи бізнесу. Встановлено, що незважаючи на позитивні тенденцї, ініціатива у прийнятті компаніями на себе зобов'язань зі сталого розвитку і відповідальності перед суспільством з 2016 року в Україні має тенденцію до зниження.

Визначено, що перевагами соціально-відповідальної політики ведення бізнесу для суб'єкта господарювання є:

- зростання позитивного іміджу підприємства;

- підвищення якості управління бізнесом;

- підвищення професіоналізму і розвиток кадрового потенщіалу;

- підвищення інвестиційної привабливості;

- створення взаємовигідних відносин з владою;

- можливість отримання додаткових пільг;

- розиирення партнерсъких зв'язків у бізнес-середовищі;

- забезпечення фінансової безпеки.

3 метою підвищення соціальної відповідальності бізнесу в Україні необхідним є реалізація таких заходів:

- проведення екологічного і соціального аудиту;

- реформування системи надання звітності відповідно до міжнародних стандартів і практик;

- мунічипальне партнерство;

- формування системи інформування суспільства про соціальні і благодійні проекти;

- організація незалежної громадської експертизи соціальних проектів;

- адаптація світового досвіду соціального підприємнищтва.

Запропоновано економічні інструменти вирішення даного питання, а саме: надання преференцій для соціально-орієнтованого бізнесу; матеріальна відповідальність за нанесення шкоди соціальним інтересам громади; екологічне страхування; розробка пропозицій місцевої влади щодо програм соціального розвитку регіонів.

Завдяки взаємодї̈ держави і підприємництва на засадах партнерства, а також наслідування успішного досвіду запровадження соиіально-орієнтованих стандартів ведення бізнесу у компаніях з різних країн світу, буде створено передумови сталого розвитку. Ці передумови основані на відповідальності суб'єктів господарювання перед навколишнім середовищем і суспільством. При иьому позитивний вплив буде не лише на суспільство і навколишнє середовище, а також сприятиме підвищенню економічної ефективності бізнесу завдяки зростанню довіри з боку суспільства.

Ключові слова: сочіальна відповідальність, взаємоузгоденість інтересів, корпоративна етика, екологізація виробництв, соціальний аудит.

\section{Introduction}

In modern conditions of globalization and integration processes, the development of entrepreneurial activity is gaining importance, in the center of which there is not only material production, but also the performance of social functions. This trend suggests a reorientation of the business strategy for maximizing profits on the strategy of maximizing social effects. In this regard, there is a need to revise the paradigm of the community of government, business and the public.
However, to date, there is some opposition between entrepreneurship and the population, which causes a certain social tension in society. The criterion of the level of development of civil society is the unity and interaction of its basic elements. For today in Ukraine a significant part of business, increasing economic efficiency of management, aspires to concentration of the goods without participation in the decision of social problems of a society. In addition, there are trends in the negligent use of natural resources, increasing environmental risks, which leads to the infringement of the rights of the population. 
On the other hand, the population strives for a uniform distribution of benefits and social justice. At the same time, the mechanism of state regulation of the creation of a social economy is imperfect. Thus, the imbalance in the coherence of the interests of the public, business and government leads to a decrease in public trust.

\section{The object of research and its technological audit}

The object of research is the organizational and economic processes of socialization of Ukrainian business.

The social responsibility of business is a manifestation of its responsibility for direct and indirect influence on the economic, environmental and social systems in which he is an integral part. In this connection, it is expedient to study the experience of foreign countries in developing the social responsibility of business in each of these systems.

One of the priority approaches to increase the social responsibility of business is considered to be measures to protect the environment. The process of developing business social responsibility in the West began as a reaction to the elimination of environmental crises and accidents, for example, dioxin leaks in Seveso (Italy), Amoco Cadiz (France) oil spill, nuclear accident in Harrisburg (USA). In response to environmental disasters, new institutions for the protection of the environment and conservation of nature have appeared, and a new legislative framework has been created. The continuation of this was the growth of social responsibility. This trend was supported at the state level and regulations were developed that provided more freedom for the company in domestic environmental policy. At the same time, laws and rules that were previously focused on one element of the environment have changed to more holistic [1].

In order to enhance environmental protection, economic incentives and administrative measures are applied, environmental subsidies, loans, taxes, fees, fines, credits and emission allowances are used. Environmental subsidies covering part of the cost of developing new environmental technologies, as well as loans for equipment for environmental purposes have an investment form in use in the countries of the European Union.

To improve the efficiency of energy saving measures and the transition to electric and hybrid vehicles, the use of alternative fuels and significant potential for additional cost-effective improvements at the level of the EU member states, economic, environmental, and safe modes of transport are used. Concerning the spread of new technologies, first of all, one should mention non-traditional energy, the most common tools for stimulating it are $[2,3]$ :

- compensation to tariffs for energy received from non-traditional types of energy (Germany, Denmark, Spain, Finland, Greece);

- exemption from tax of a part of the profit invested in the development of non-conventional energy (Netherlands);

- release of consumers of «clean» energy from environmental taxes (Sweden, France);

- tenders and quotas «green certificates» in support of various widows of non-traditional types of energy from the general special fund (Great Britain, Ireland); - direct subsidies, soft loans, tax credits (Austria).

Taking into account the above-mentioned modern level, it is necessary to form an adequate strategy for the behavior of the Ukrainian business in terms of the burden on the environment and limiting the negative impact on ecosystems.

The use of the system approach has made it possible to combine environmental issues with economic ones. To this end, economic instruments have been introduced, such as the emissions trading scheme, in particular the flexible mechanisms of the Kyoto Protocol. However, the economic component of the social responsibility of business is not limited only to environmental activities. The combination of all components of the social responsibility of business is reflected in the International Standard ISO 26000:2010 «Guide to Social Responsibility» [4, 5].

One of the priority areas for the development of companies is the development of ethical behavior, which is a prerequisite for their sustainable development. The instrument is the concept of sustainable development of the United Nations, which is based on the need to harmonize the interests of generations to achieve economic prosperity, social well-being and a safe environment.

\section{The aim and objectives of research}

The aim of research is determination of the theoretical foundations and the rationale for practical tools for increasing the social responsibility of business and its adaptation to global requirements on the basis of transparent and ethical behavior.

The realization of the goal determined the solution of the following scientific problems:

1. To analyze the tendencies of the responsibility of Ukrainian business to society.

2. To determine the advantages of a socially responsible business policy for the enterprise.

3. To identify the organizational and economic components of enhancing the social responsibility of business.

\section{Research of existing solutions of the problem}

The work of a significant circle of scientists is devoted to the study of theoretical and practical aspects of the social responsibility of business [6-9]. To date, a significant number of Ukrainian enterprises understand that social policy is a prerequisite for sustainable development based on the responsibility of business entities to the environment and society [1, 10-12]. However, the understanding of the essence of social responsibility by Ukrainian enterprises differs somewhat from its understanding by foreign colleagues. Thus, the difference in understanding the essence of the social responsibility of business at the world level is not limited to charitable activity, but is one of the tools to enhance the image of the enterprise and to establish links with the authorities, partners, shareholders and society $[13,14]$. In this regard, a number of problematic aspects that impede the development of Ukrainian enterprises are identified based on a socially-oriented business. The desire of business entities to the rapid growth of profits forces management to refuse to transfer part of their income to social programs, as well as the reluctance of businesses to attract attention to their incomes. It is determined that insufficient awareness of society about social programs and their successful implementation leads to a lack of understanding of the role of each citizen in the development of social responsibility [15]. 
The concept of corporate social responsibility is actively promoted and implemented at the international level. The basis of social responsibility at the international level is recognized by the UN activities, which support in this sphere is reflected in the UN Global Compact [16], within which conditions are created for cooperation with a view to implementing the principles of social equality and preservation of the environment. The combination of all components of the social responsibility of business is reflected in the International Standard ISO 26000:2010 «Guide to Social Responsibility» $[4,5]$, allows to assess non-financial aspects of economic activity and the quality of management decisions.

The main problems of the development of civil society in Ukraine, including the social responsibility of business, and their consequences are presented in the «National Strategy for the Development of Civil Society in Ukraine for 2016-2020» [17]. However, the mechanisms of interaction between government and business in it are very limited, since the emphasis is on the organization of civil society.

It is determined that the social responsibility of Ukrainian business can't be formed only on the enthusiasm of business entities. The practice of many countries in Europe shows that power should support and stimulate socially responsible behavior [2, 3]. For Ukraine, the declarative nature of the legislative base for supporting social initiatives remains a problematic issue.

It is established that for today in Ukraine the subjects of socially responsible business are large companies. An example of this can serve LLC «NIBULON», which in its activities adheres to international business standards and disseminates the practice of social responsibility of business [13]. Mobile communication company «Kyivstar» in its strategy assumes responsibility for the product, responsibility to the state, development of personnel, contribution to society and protection of nature. The social policy of Sandora is sponsored by children's homes, providing financial assistance and vitamin products to vulnerable groups of the population, supporting talented youth and youth leadership initiatives. A positive aspect is the implementation of the company's social policy, rather than one-off shares. However, due to the limited financial resources and other factors, the social policy of small enterprises is somewhat limited.

Thus, the results of the analysis lead to the conclusion that further research in the field of social economics will require the efforts of the scientific community. This is due to a change in the socio-economic conditions of management and the need to identify pressing problems and the search for directions for their solution.

\section{Methods of research}

Theoretical and methodological basis of the research is general scientific and special methods of scientific knowledge, fundamental provisions of economic theory, scientific works on solving problem aspects of ensuring social responsibility of business.

Depending on the direction of certain tasks, the following methods of scientific research are used: - scientific abstraction (in the formation of the goal, objectives and conclusions of the study); - bibliographic (in the process of processing scientific papers that are devoted to the social responsibility of business entities);
- method of logical generalization (in the study of the prerequisites for the spread of the concept of social responsibility of business);

- monographic (in the course of studying the best practices of foreign countries on the formation and development of corporate social responsibility of business and determining the possibilities for its adaptation to the conditions of Ukraine);

- calculated, comparative and graphical (in the course of analysis of Ukraine's position on the Global Competitiveness Index and its components);

- system approach (in determining the levers for regulating the formation and use of the resource potential of Ukraine and the organizational and economic components of the social responsibility of business).

\section{Research results}

Social responsibility of business is a set of principles, mechanisms and actions of the business entity in the course of relations with the society, authorities, population and other business entities. An important condition here is achievement of harmonization and satisfaction of social, economic, financial, ethical interests of all parties with partial or full compensation of market insolvency and restrictions [13].

The importance of developing the social economy of Ukraine was recognized in 2006 with the accession to the Global Compact networking initiative. At the same time, such initiative showed high results. This was confirmed by the recognition of Ukraine along with Japan and Serbia in 2009, as one of the three most successful Global Compact networks in the world. For today in Ukraine about 200 companies have become signatories of the Global Compact.

The World Economic Forum is conducting a global study of the world's countries on the indicator of economic competitiveness - the Global Competitiveness Index. At its core, this index assesses the ability of countries to ensure a high level of provision of their citizens, and, accordingly, determines the level of unity of the components of civil society. According to the results of the Global Competitiveness Rating, the figures presented in Fig. 1, rather low positions of Ukraine should be noted. During the study period Ukraine's highest position was in 2012-2013, and the lowest in 2016-2017, losing 12 points.

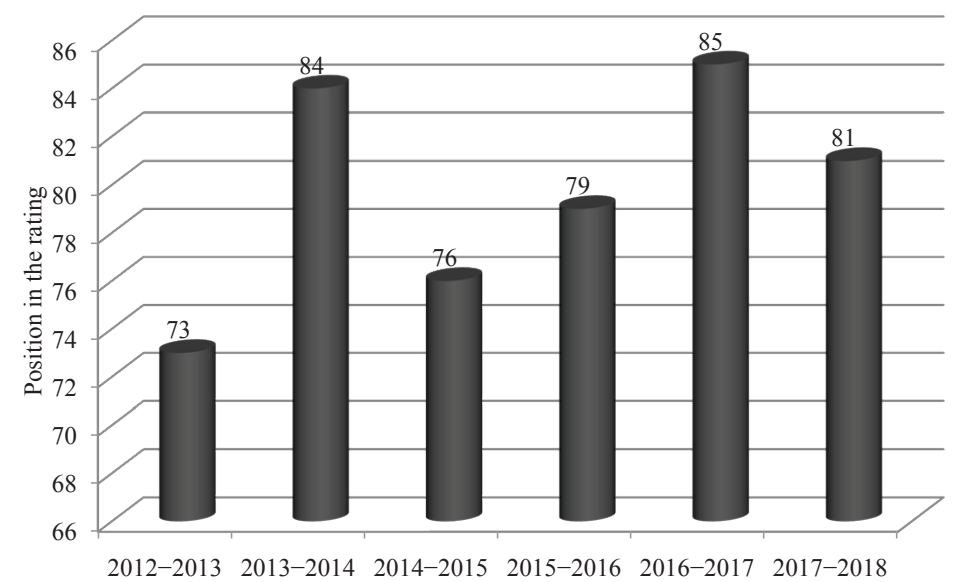

Fig. 1. Dynamics of Ukraine's position on the Global Competitiveness Index [18] 
Despite positive trends, the initiative in taking on the companies' obligations on sustainable development and responsibility to the society since 2016 has a tendency to decrease. According to the results of the Global Competitiveness rating, which also takes into account social initiatives of business, Ukraine occupies not high positions (Table 1).

On such component of the index, as corporate ethics, Ukraine ranks 102 out of 137 countries in the 2017-2018 rating. Ukraine ranks 76th among 140 countries compared with the 2015-2016 rating for this component. According to the data, Ukraine also worsened its position on the component «Flexibility of determining wages» and lost 49 points in 2017-2018 compared with 2014-2015.
- organization of an independent public examination of social projects;

- adaptation of the world experience of social entrepreneurship.

The prerequisite for sustainable development of business entities is the formation of the image of a socially responsible subject of public relations. An important tool in the study of the level of social responsibility of business is a social audit, the expediency of which for the enterprises themselves is explained by the opportunity to confirm their position on social issues.

As a specific form of control, social audit becomes important in the process of society humanization and the recognition by its representatives of the fact that their well-being depends on the results of

Table 1 the activities of economic structures and the consequences of their impact on the functioning environment [20].

As part of the social audit, a significant range of objects is studied, namely: working conditions; labor relations in the company; compliance with labor protection requirements; attitude to the principles of environmental friendliness and so on.
Despite some shifts in the behavior of commercial organizations on the positive attitude to the aspects of social responsibility, more than a third of business structures do not participate in social support. An objective factor of not being ready for social investment is the underdevelopment and insecurity of the business sector itself.

However, according to the National Institute for Strategic Studies, an interesting fact of recent years is that the population expects charitable assistance primarily from commercial structures, but from the state [19]. This is an indication that the public's confidence in Ukrainian business is growing.

According to the research results, the organizational and economic components of the social responsibility of business are defined, as shown in Fig. 2.

Achievement of a specific goal can be ensured by the implementation of organizational and economic components. The organizational components of increasing the social responsibility of business are:

- conducting social audit;

- reforming the reporting sys-

tem in accordance with interna-

tional standards and practices;

- municipal partnership;

- formation of a system for informing the public about social and charitable projects;



Fig. 2. Organizational and economic components of social responsibility of business 
Important aspects of further development are the interest of the business environment in the implementation of environmental measures, the establishment of responsibility for environmental violations when using resources. This requires strengthening the control function and increasing social responsibility and the level of environmental awareness. Fig. 3 shows the directions and components of the country's environmentally-oriented development.

Most owners and heads of enterprises are not intended to solve the problems of greening production. One of the reasons is the lack of motivation and appropriate incentives, as well as the need to attract additional financial resources, indicating the orientation is mainly to obtain economic interests. Motivational directions and compliance of incentives in the business environment should be guided by understanding the consequences of activities, obtaining socially useful interests from environmentally oriented activities, the desire to improve the quality of life of society using «eco-technology».

The modern environmental situation prompts the need for environmental education and ensuring environmental ethics in the conduct of business. The main levers for stimulating environmental awareness and responsible attitude to the environment include environmental insurance, environmental audit, improvement of the system of effective use of natural resources by species.

Environmental insurance, environmental audit are considered to be the main levers for stimulating environmental consciousness (Fig. 4). Practical implementation of these tools provides not only the results of enterprises, but also creates a positive image, a favorable investment climate and reduces the level of environmental threats in individual territories.

As practice shows, the mass consciousness of most people is dominated by the motives of activity, related only directly to short-term goals (day, week, month, year). This is not enough, since an objective assessment is excluded not only of those trends in the development of society that have already developed, but also of the final results of long-term joint livelihoods. Immersed in the hustle and bustle of current affairs and entertainments, the individual often does not want to part with the entrenched habits, so he does not perceive any knowledge, takes him out of the circle of habitual activity. But yesterday it was still acceptable, today it is dangerous, and tomorrow it can already become unacceptable [11].

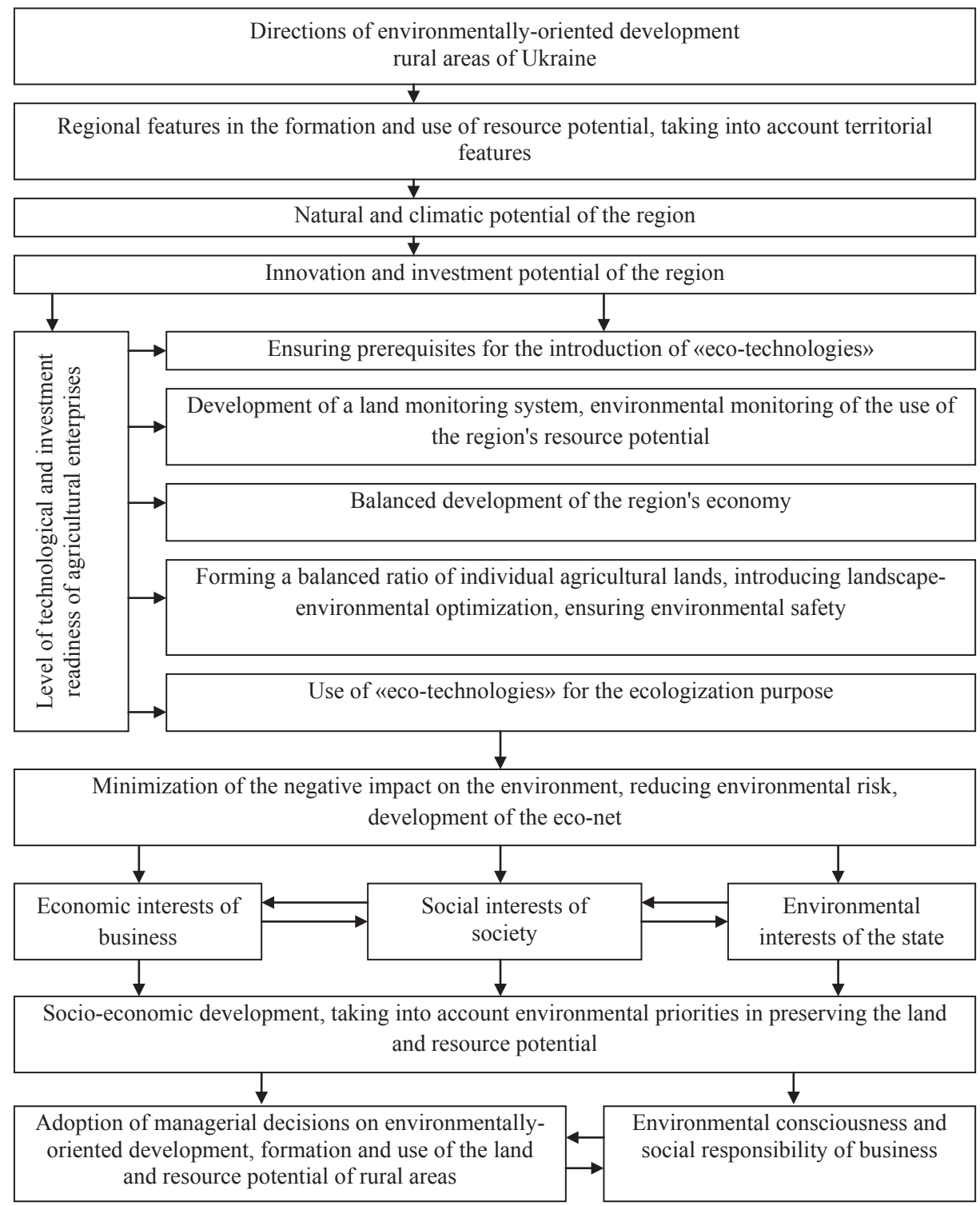

Fig. 3. Approaches and prerequisites for the environmentally oriented development of Ukraine 


\begin{tabular}{|c|c|}
\hline $\begin{array}{l}\text { ENVIRONMENTAL } \\
\text { INSURANCE }\end{array}$ & $\begin{array}{l}\text { Insurance of liability of enterprises for causing damage in } \\
\text { connection with an accident, technological failure or natural } \\
\text { disaster, leading to environmental pollution }\end{array}$ \\
\hline \multicolumn{2}{|c|}{$\begin{array}{r}\text { Provision of a system of balances between the inte } \\
\text { with a view to creating a favorable basis for the effec } \\
\text { and the use of natura }\end{array}$} \\
\hline \multicolumn{2}{|c|}{$\begin{array}{c}\text { Ensuring of environmental sustainability of production processes at enterprises and reducing } \\
\text { business risks }\end{array}$} \\
\hline $\begin{array}{l}\text { ENVIRONMENTAL } \\
\text { AUDIT }\end{array}$ & $\begin{array}{l}\text { Environmental independent verification of the economic activities } \\
\text { of the enterprise with the aim of assessing its responsibility to } \\
\text { environmental legislation and developing recommendations for } \\
\text { reducing actual or potential environmental, financial and other } \\
\text { losses and expenses }\end{array}$ \\
\hline \multicolumn{2}{|c|}{$\begin{array}{c}\text { Control over the formation of environmental costs at the place of their occurrence with the } \\
\text { identification of deviations from the norms regulating the balanced nature management, as } \\
\text { well as the identification of extensive and intensive factors and reserves of environmental } \\
\text { activities of primary divisions }\end{array}$} \\
\hline \multicolumn{2}{|r|}{1} \\
\hline \multicolumn{2}{|c|}{$\begin{array}{l}\text { Improvement of the production and economic activities of enterprises, taking into account and } \\
\text { improving the economic, financial, technological strategy to improve the level of } \\
\text { environmental friendliness of enterprises operating in rural areas }\end{array}$} \\
\hline
\end{tabular}

Fig. 4. The main levers of regulation of the processes of formation and use of the resource potential of the agrarian sector of Ukraine [12, 21]

The practical implementation of these mechanisms improves not only the performance of the enterprise, but also creates a positive image, a favorable investment climate and raises the level of competitiveness of the commodity producer.

Consequently, in the context of the urgency of implementing an environmentally oriented structural adjustment of the economy, it is necessary to introduce nature management into the sphere of formed market relations. For this, it is necessary to improve the general model of environmental management at the state level, taking into account social responsibility and environmental awareness in conducting business.

The implementation of the proposed tools at the local level is possible in different scenarios, one of which is the construction of corporate social responsibility in the enterprise. The success of such scenario depends, first of all, on the interest of management. Therefore, the support of management in the implementation of goals, including financial, is the key to the effectiveness of the activities. The next step is determination of the budget that the company can provide for the events. At the same time, the measures developed must necessarily be coordinated with the goals of corporate social responsibility. The objectives of enterprises in this direction are different and can be as follows:

- raise the level of professional qualifications of employees;

- increase the level of satisfaction with work;

- receiving certain rewards;

- participation in social programs and the like.

The rationale and development of measures for the formation of corporate social responsibility of an enterprise should be coordinated with its overall strategy and may be implemented by a separate department or an initiative group.
Thus, the formation of an effective model of corporate social responsibility has as its objective the interests of the authorities, business and the public. The interaction of the state and business on the principles of partnership, as well as imitating the successful experience of introducing socially-oriented business standards of international and Ukrainian companies will create the prerequisites for sustainable development based on the responsibility of business entities to the environment and society.

\section{SWOT analysis of research results}

Strengths. The strong point in the conducted research is the analysis of tendencies of development of social responsibility of business in Ukraine and definition on this basis of organizational-economic components of its increase. The advantages of a socially responsible business policy for enterprises are determined.

Weaknesses. The weak side is that despite some shifts in the behavior of commercial organizations on the positive attitude to the aspects of social responsibility, more than a third of business structures do not participate in social support. An objective factor of not being ready for social investment is the underdevelopment and insecurity of the business sector itself. Considering the fact that Ukrainian enterprises are in languages of significant tax burden, conducting an environmental audit and implementing environmental insurance will lead to an increase in costs. This does not contribute to the growth of profitability, and, accordingly, the opportunities for financing social activities.

Opportunities. Opportunities for further research are the introduction of the experience of foreign countries on public policy to stimulate the ecologization of industries. Further research can be aimed at studying the experience of Ukrainian companies in the formation of corporate social 
responsibility in order to identify key aspects of success and develop practical recommendations on this basis. For enterprises, they identified the need to introduce social policy, it is possible to use such a tool as benchmarking.

Threats. Threats to the results of the conducted studies are that dynamic changes in the world economy will require improvement of the methodology of the rating according to the Global Competitiveness Index. In addition, requires the standardization of social reporting, which is an indicator of the social responsibility of business. For Ukrainian enterprises, taking into account the imperfection of the current legislation, artificial barriers to the implementation of social initiatives are created and the «interest» on the part of state control bodies to enterprises that implement social activities is growing.

\section{Conclusions}

1. The dynamics of Ukraine's position on the Global Competitiveness Index is analyzed, which also takes into account the social initiatives of business. Despite positive trends, the initiative in taking on the companies' obligations for sustainable development and responsibility to the society since 2016 has a tendency to decrease. So, for such component of the Index as corporate ethics, Ukraine ranks 102nd out of 137 countries in the 2017-2018 rating. Ukraine ranks 76th among 140 countries compared with the 2015-2016 rating for this component. According to the data, Ukraine also worsened its position on the component «Flexibility of determining wages» and lost 49 points in 2017-2018 compared with 2014-2015.

2. It is determined that the advantages of a socially responsible business policy for an enterprise are:

- growth of the company's positive image;

- improving the quality of business management;

- increase of professionalism and development of personnel potential; increase of investment attractiveness; - creation of mutually beneficial relations with the authorities;

- possibility of obtaining additional benefits;

- expansion of partnerships in the business environment;

- ensuring financial security.

3. Organizational and economic components are singled out, the implementation of which is aimed at increasing the social responsibility of business. Organizational components are:

- carrying out environmental and social audit;

- reforming the reporting system in accordance with

international standards and practices;

- municipal partnership;

- formation of a system for informing the public about social and charitable projects;

- organization of an independent public examination of social projects;

- adaptation of the world experience of social entrepreneurship.

The economic components are as follows:

- preferences for business;

- material responsibility for harming the social interests

of society;

- proposals of the local authorities on the programs of social development of the regions.

\section{References}

1. Zhuk A. Korporatyvna sotsialna vidpovidalnist - tse ne lyshe vydatky, a y koryst // Ekolohiia pidpryiemstva. 2017. Vol. 9. URL: http://ecolog-ua.com/articles/korporatyvna-socialna-vidpovidalnist-ce-ne-lyshe-vydatky-y-koryst

2. Bokovykova Yu. V. Dosvid pryrodokorystuvannia yevropeiskykh krain // Derzhavne budivnytstvo. 2016. Vol. 1. URL: http:// www.kbuapa.kharkov.ua/e-book/db/2016-1/doc/4/01.pdf

3. Klavdienko V. P. Tarasov A. P. Netraditsionnaya energetika v stranakh ES: ekonomicheskoe stimulirovanie razvitiya. URL: http://www.roman.by/r-78807.html

4. ISO 26000:2010 - Guidance on social responsibility. URL: https://www.iso.org/standard/42546.html

5. Naden C. The rise of being «social». 2017. URL: https:// www.iso.org/news/ref2204.html

6. Carroll A. B. Corporate Social Responsibility // Business \& Society 1999. Vol. 38, No. 3. P. 268-295. doi:10.1177/000765039903800303

7. McWilliams A., Siegel D. Corporate Social Responsibility: A Theory Of The Firm Perspective // Academy of Management Review. 2001. Vol. 26, No. 1. P. 117-127. doi:10.5465/amr.2001.4011987

8. Winnett A., Lewis A. You'd Have to Be Green to Invest in This: Popular Economic Models, Financial Journalism, and Ethical Investment // Journal of Economic Psychology. 2000. Vol. 21, No. 3. P. 319-339. doi:10.1016/s0167-4870(00)00007-6

9. Mirvis Ph., Googins B. K. Stages of Corporate Citizenship: A Developmental Framework. Chestnut Hill: Centre for Corporate Citizenship at Boston College, 2006. 21 p.

10. Vyshnevska O. M., Bobrovska N. V. Pryrodno-resursna osnova rozvytku ahrarnoho sektoru: teoretychni i praktychni aspekty: monograph. Mykolaiv, 2015. 180 p.

11. Akulenko V. L., Mamchuk I. V. Ekolohichnyi menedzhment v konteksti zabezpechennia ekolohichnoi bezpeky pidpryiemstva // Visnyk Khmelnytskoho natsionalnoho universytetu. 2009. Vol. 1, No. 5. P. 21-26.

12. Skrebets V. O. Ekolohichna psykholohiia u viddalenykh naslidkakh ekotekhnohennoi katastrofy: monograph. Kyiv: Slovo, 2004. 440 p.

13. Ivanytska $\mathrm{O}$. Hlobalni standarty sotsialnoi vidpovidalnosti biz nesu. Nezalezhnyi Audytor. URL: http://n-auditor.com.ua/uk/ component/na_archive/1241?view=material

14. Sochneva E. N., Shaburova D. Ya. Sotsial'naya otvestvennost' biznesa: byloe i dumy // Postulat. 2016. Vol. 12. URL: http://e-postulat.ru/index.php/Postulat/article/view/288/305

15. Dovydenko N. A., Tubich A. G. Rol' i mesto sotsial'noy otvetstvennosti v upravlenii sovremennymi belorusskimi organizatsiyami // Vestnik Brestskogo gosudarstvennogo tekhnicheskogo universiteta. 2012. Vol. 3. P. 49-50.

16. Global network of UN Global Compact. URL: http://www. unglobalcompact.org/index.html

17. Natsionalna stratehiia spryiannia rozvytku hromadianskoho suspilstva v Ukraini na 2016-2020 roky: Decree of the President of Ukraine No. 68/2016 from 26.02.2016 // Baza danykh «Zakonodavstvo Ukrainy». URL: http://zakon2.rada.gov.ua/laws/ show $/ 68 / 2016$

18. Ekonomichnyi dyskusiinyi klub. URL: http://edclub.com.ua/ analityka/pozyciya-ukrayiny-v-reytyngu-krayin-svitu-za-indeksomglobalnoyi-konkurentospromozhnosti-2

19. Natsionalnyi instytut stratehichnykh doslidzhen. URL: http:// old.niss.gov.ua

20. Holinach L. I. Essence of social audit in the process of adoption of business social responsibility // Ekonomichnyi analiz. 2015. Vol. 18, No. 2. P. 113-117.

21. Ekolohichnyi audyt: handbook / Shevchuk V. Ya. et al. Kyiv, 1997. 221 p.

Klochan Vira, PhD, Associate Professor, Department of Accounting and Taxation, Mykolayiv National Agrarian University, Ukraine, e-mail: klochanvp@mnau.edu.ua, ORCID: https://orcid.org/00000002-4946-213X

Kostyrko Alla, PhD, Senior Lecturer, Department of Accounting and Taxation, Mykolayiv National Agrarian University, Ukraine, e-mail: kosturkoa@gmail.com,ORCID: https://orcid.org/0000-00022043-1348

Bobrovskaya Nadiya, PhD, Senior Lecturer, Department of Accounting and Taxation, Mykolayiv National Agrarian University, Ukraine, e-mail: bobrovskanadia@gmail.com, ORCID: https:// orcid.org/0000-0001-9178-0425 